\title{
HEMATOLOGIC AND CLINICAL INDICES OF MALARIA IN A SEMI-IMMUNE POPULATION OF WESTERN THAILAND
}

\author{
LAURA M. ERHART, KRITSANAI YINGYUEN, NIPHON CHUANAK, NILAWAN BUATHONG, \\ ANINTITA LAOBOONCHAI, R. SCOTT MILLER, STEVEN R. MESHNICK, ROBERT A. GASSER JR., AND \\ CHANSUDA WONGSRICHANALAI \\ Armed Forces Research Institute of Medical Sciences, Bangkok, Thailand; University of Michigan School of Public Health, Ann \\ Arbor, Michigan; University of North Carolina School of Public Health, Chapel Hill, North Carolina; Walter Reed Army Institute of \\ Research, Silver Spring, Maryland
}

\begin{abstract}
This study examines hematologic profiles of persons with acute Plasmodium falciparum or P. vivax infection in Maesod on Thailand's western border with Myanmar compared with febrile, non-parasitemic persons also reporting to malaria clinics. Nine hundred seventy-nine subjects were malaria-negative, 414 were infected with $P$. falciparum, and 646 were infected with $P$. vivax. Persons with patent parasitemia tended to have significantly lower white blood cell, red blood cell, platelet, and hemoglobin levels than those who were malaria-negative. For the first time, a parallel trend in thrombocytopenia with parasitemia was found to be associated with both $P$. falciparum, and $P$. vivax infection. Using logistic regression, persons with platelet counts $<150,000 / \mu \mathrm{L}$ were $12-15$ times more likely to have malaria than persons with platelet counts $\geq 150,000 / \mu \mathrm{L}$. This study supplements previous literature on the hematologic effects of malaria and helps define those alterations for a semi-immune population. Thrombocytopenia is identified as a key indicator of malaria in these febrile patients.
\end{abstract}

\section{INTRODUCTION}

The prevalence of malaria in Thailand has decreased dramatically from previous levels, but regions of the country are still affected. Approximately $40 \%$ of the 150,000 malaria cases detected in Thailand annually are foreign migrants and among them $97 \%$ are from Myanmar and Cambodia (Thai Ministry of Public Health Malaria Statistics, 2000). Tak province, on the central part of the Thailand-Myanmar border, is the most common destination for ethnic minorities from Myanmar who migrate into Thailand and become engaged in agricultural work. This province has had the highest number of malaria cases for 10 consecutive years. Plasmodium vivax and P. falciparum are both common.

Hematologic changes associated with malaria infection are well recognized, but specific changes may vary with level of malaria endemicity, background hemoglobinopathy, nutritional status, demographic factors, and malaria immunity. ${ }^{1}$ This study examines the hematologic effects of acute malaria on adults in Tak Province. Specifically, the hematologic profiles of persons infected with $P$. falciparum or $P$. vivax are compared with expected normal values, as well as with the profiles of otherwise similar febrile persons without microscopically detectable parasitemia. Additionally, the clinical symptoms and hematologic parameters most predictive of malaria in this population are identified.

\section{SUBJECTS AND METHODS}

Data used in this study were collected as part of a series of study to evaluate malaria rapid diagnostic devices. ${ }^{2}$ The study was reviewed and approved by the Thai Ministry of Public Health Ethical Review Committee for Research in Human Subjects and the U.S. Army's Human Subjects Research Review Board. Patients were recruited from May 18, 2001 through June 29, 2001 from malaria clinics operated by the Thai Ministry of Public Health in the Mae Ku, Maesod, and Phob Phra Districts of Tak Province, Thailand. The study population is composed largely of migrant workers from Myanmar. Inclusion criteria were presentation to a participating clinic site for malaria diagnosis and treatment; age $\geq 20$ years; and at least one of the following: an oral temperature $\geq 38^{\circ} \mathrm{C}$, headache, or a history of fever within the past 72 hours. Severely ill patients were referred to district hospitals; therefore, complicated malaria cases were excluded in practice. Each patient was assigned a unique patient identifier. All enrolled patients were interviewed in their own vernacular language, Thai, Burmese, or Karen, for information on current symptoms and previous malaria episodes and treatments. Venous blood was drawn into EDTA-filled tubes to be used for preparation of blood film slides and automated complete blood counts (CBCs). Two slides for study purposes were promptly prepared at the field site, each with a thin and thick smear. A third smear was prepared and provided immediately to the local clinic staff to be stained and interpreted according to routine clinic procedures for therapeutic purpose.

Tubes were transported on ice within two hours to the field laboratory, where cell counts were performed using a Coulter T-890 automated cell counters (Beckman-Coulter, Inc, Fullerton, CA). Daily quality assurance checks were performed and recorded, and commercial standards were used in accordance with the manufacturer's recommendations. The cell counters provided data on the white blood cell count (WBC), red blood cell count (RBC), hemoglobin level $(\mathrm{Hb})$, hematocrit, mean corpuscular volume, mean corpuscular hemoglobin, mean corpuscular hemoglobin concentration, platelet count, lymphocyte count, and lymphocyte percent.

Blood smear slides were stained with Giemsa. One slide from each study participant was examined independently by two experienced microscopists. They determined the presence or absence of Plasmodia parasites, the species, and the number of asexual parasites per 200 WBCs. If fewer than 10 asexual parasites per $200 \mathrm{WBCs}$ were observed, counting continued to 500 WBCs. Parasite densities were calculated as parasites per microliter of blood (parasites/WBCs counted $\times$ total WBCs in $1 \mu \mathrm{L}$ of blood), and the results of the two readings were averaged. Concordance between the two blinded microscopists' interpretations was assessed and cases of species discordance from the two readings, mostly associ- 
ated with very low parasitemia, were excluded from this analysis.

Data were analyzed using SAS version 8.1 (SAS Institute, Cary, NC). Patients were categorized based on microscopy results: no malaria (control group), $P$. falciparum detected, $P$. falciparum at densities greater than 1,000 parasites/ $\mu \mathrm{L}, P$. vivax detected, $P$. vivax at densities greater than 1,000 parasites $/ \mu \mathrm{L}$, mixed $P$. falciparum $/ P$. vivax infection, or $P$. malariae detected. Mean hematologic parameters were calculated by sex for the control group (who also presented with fever, headache, or a history of fever). Hematologic parameters were compared between the control group and the specific malaria groups using independent-sample $t$-tests. Parasite densities for single-species infections were divided into quartiles, and their associations with the hematologic parameters were detected using analysis of variance.

To test for an association between malaria and symptoms or specific hematologic values, categorical variables were created for platelets, RBCs, and WBCs. Bivariate associations were examined between these variables or clinical symptoms and various outcomes: any malaria, $P$. falciparum, $P$. vivax, mixed infection, $P$. malariae, $P$. falciparum $>1,000$ parasites/ $\mu \mathrm{L}, P$. vivax $>1,000$ parasites $/ \mu \mathrm{L}$, or the lower densities for either species. Variables significant in any of these analyses were fit into logistic regression models to identify factors that were collectively predictive of malaria. Each malaria outcome was modeled separately, and stepwise selection was used to identify the variables with the most predictive value for each outcome.

\section{RESULTS}

Two thousand one hundred forty-nine subjects were enrolled in the study. Their mean age was 28 years (range = 20-70 years), and $69 \%$ were men. Seventy participants were excluded from the analysis because only gametocytes were detected $(n=6)$ or because of species discordance in the readings of the two microscopists $(n=64)$. Asexual malaria parasites were observed in the blood smears of 1,100 participants, and 979 had negative blood films. Of the malariapositive slides, $646(59 \%)$ were $P$. vivax, 414 (38\%) were $P$. falciparum, $23(2 \%)$ were mixed $P$. falciparum and $P$. vivax infections, $15(1 \%)$ were $P$. malariae, and $2(0.2 \%)$ were $P$. ovale.

The mean values of selected hematologic parameters for the negative (control) group were determined for this population, stratified by sex (Table 1). T-tests showed that RBCs, $\mathrm{Hb}$, platelet count, and lymphocyte count were significantly different between men and women without malaria, so subsequent analysis of continuous variables was stratified by sex. For comparison, Table 1 also includes published normal values, although derived from a population from the United States and with relatively wide ranges. ${ }^{3}$ All the values from this study population fall within the acceptable normal limits.

Hematologic parameters of participants in each of the malaria outcomes were compared with those of the sex-specific control group using independent-sample $t$-tests. Results are shown by sex and parasite species in Table 2. For $P$. falciparum and $P$. vivax, the mean values of WBCs, RBCs, platelet counts, and lymphocyte counts were significantly lower for the infected groups than for the uninfected groups among
TABLE 1

Comparison of mean values of hematologic parameters for nonmalarious subjects by sex

\begin{tabular}{clrrrr}
\hline \multicolumn{1}{c}{ Parameter } & & No.* & Mean & $P$ & $\begin{array}{c}\text { Published } \\
\text { values }\end{array}$ \\
\hline White blood cells & Men & 615 & 8.27 & & $4.5-11.0$ \\
$\left(10^{3} / \mu \mathrm{L}\right)$ & Women & 363 & 8.49 & & $4.5-11.0$ \\
& Difference & & -0.22 & 0.23 & \\
Red blood cells & Men & 615 & 4.97 & & $4.6-6.2$ \\
$\quad\left(10^{6} / \mu \mathrm{L}\right)$ & Women & 363 & 4.52 & & $4.2-5.4$ \\
& Difference & & 0.45 & $<0.0001$ & \\
Hemoglobin & Men & 615 & 13.77 & & $13.5-18.0$ \\
$(\mathrm{~g} / \mathrm{dL})$ & Women & 363 & 11.91 & & $12.0-16.0 \ddagger$ \\
& Difference & & 1.86 & $<0.0001$ & \\
Platelets & Men & 615 & 245.0 & & $150-400$ \\
$\left(10^{3} / \mu \mathrm{L}\right)$ & Women & 363 & 290.6 & & $150-400$ \\
& Difference & & -45.6 & $<0.0001$ & \\
Lymphocytes & Men & 615 & 2.43 & & $1.0-4.8$ \\
$\left(10^{3} / \mu \mathrm{L}\right)$ & Women & 363 & 2.73 & & $1.0-4.8$ \\
& Difference & & -0.30 & $<0.0001$ & \\
\hline
\end{tabular}

* One subject had missing sex information.

$\dagger$ Mazza. $^{3}$

\# Anemia is sometimes defined as a hemoglobin level $<12 \mathrm{~g} / \mathrm{dL}$ for men and $<10 \mathrm{~g} / \mathrm{dL}$ for women. ${ }^{6}$

both men and women. The exclusion of persons with parasite densities less than 1,000 parasites/ $\mu \mathrm{L}$ did not yield substantially different results. Although sample sizes for $P$. malariae and mixed infections were small, similar trends were observed in these groups.

Parasitemias for $P$. falciparum ranged from 10 to 687,622 parasites $/ \mu \mathrm{L}$; parasitemias for $P$. vivax ranged from 9 to 225,006 parasites $/ \mu L$. Analysis of variance was used to identify relationships between hematologic parameters and parasite densities. Platelet count was the only parameter for any group that showed a trend across quartiles of parasite densities. The mean platelet count was significantly lower in men and women with higher parasitemia for either $P$. falciparum or P. vivax (Table 3 and Figure 1).

Categorical variables were created from three of the hematologic parameters: WBC, RBC, and platelet counts. Along with age and clinical symptoms, these variables were tested for independent associations with type of malaria as shown in Table 4. A WBC $<5,000 / \mu \mathrm{L}$, a RBC $<4,000,000 / \mu \mathrm{L}$, a platelet count $<150,000 / \mu \mathrm{L}$, an oral temperature $\geq 38.5^{\circ} \mathrm{C}$, a history of fever in the past 72 hours, malaise, and chills were all significantly more likely to occur in persons with any malaria, $P$. falciparum, or $P$. vivax, than in persons with a negative blood film. Low WBC, RBC, and platelet counts were also significant for persons with $P$. malariae, despite the small sample size for this group. Vomiting was a significant predictor in persons with any malaria or $P$. falciparum. Myalgias and lack of cough were significant for any malaria and $P$. vivax. Analysis of persons with high levels of parasitemia produced very similar results to any parasitemia; the lower parasitemia categories showed similar tendencies but with reduced strength and significance.

Factors significant for any of the malaria categories were fit to a logistic regression model using stepwise selection to determine the most significant predictors of malaria for each outcome and the results are shown in Table 5. The three hematologic parameters were significant predictors for the presence of malaria, with the exception of RBCs in $P$. vivax infections. Platelet count showed the strongest association and had the greatest predictive power in each of the models; 
TABLE 2

Hematologic values in persons with positive malaria smears compared to the negative control group by sex

\begin{tabular}{|c|c|c|c|c|c|}
\hline \multirow[b]{2}{*}{ Parameter } & & \multicolumn{2}{|c|}{ Men } & \multicolumn{2}{|c|}{ Women } \\
\hline & & No.* & $\begin{array}{c}\text { Mean } \\
\text { (median) }\end{array}$ & No.* & $\begin{array}{c}\text { Mean } \\
\text { (median) }\end{array}$ \\
\hline \multirow[t]{5}{*}{ White blood cells $\left(10^{3} / \mu \mathrm{L}\right)$} & Negative & 615 & 8.27 & 363 & 8.49 \\
\hline & P. falciparum & 325 & $6.22 \dagger$ & 89 & $6.28 \dagger$ \\
\hline & $P$. vivax & 459 & $6.71 \dagger$ & 186 & $6.39 \dagger$ \\
\hline & Mixed $P f / P v$ & 19 & $6.58 \ddagger$ & 4 & 5.88 \\
\hline & P. malariae & 14 & $5.57 \dagger$ & 1 & - \\
\hline \multirow[t]{5}{*}{ Red blood cells $\left(10^{6} / \mu \mathrm{L}\right)$} & Negative & 615 & 4.97 & 363 & 4.52 \\
\hline & P. falciparum & 325 & $4.62 \dagger$ & 89 & $4.34 \S$ \\
\hline & $P$. vivax & 459 & $4.79 \dagger$ & 184 & $4.28 \dagger$ \\
\hline & Mixed $P f / P v$ & 19 & 4.76 & 4 & $3.68 \ddagger$ \\
\hline & P. malariae & 14 & $4.41 \dagger$ & 1 & - \\
\hline \multirow{5}{*}{ Hemoglobin (g/dL) } & Negative & 615 & 13.77 & 363 & 11.91 \\
\hline & P. falciparum & 325 & $12.93 \dagger$ & 89 & 11.51 \\
\hline & $P$. vivax & 459 & $13.44 \ddagger$ & 186 & $11.59 \S$ \\
\hline & Mixed $P f / P v$ & 19 & 13.00 & 4 & 10.93 \\
\hline & P. malariae & 14 & $11.85 \dagger$ & 1 & - \\
\hline \multirow[t]{5}{*}{ Platelets $\left(10^{3} / \mu \mathrm{L}\right)$} & Negative & 615 & $245.0(240.0)$ & 363 & $290.6(278.0)$ \\
\hline & P. falciparum & 325 & $126.3 †(114.0)$ & 89 & $133.6 \dagger(130.0)$ \\
\hline & $P$. vivax & 459 & $140.4 \dagger(131.0)$ & 186 & $160.7+(141.0)$ \\
\hline & Mixed $P f / P v$ & 19 & $125.2 \dagger$ & 4 & 228.8 \\
\hline & P. malariae & 14 & $139.1 \dagger$ & 1 & - \\
\hline \multirow{5}{*}{ Lymphocytes $\left(10^{3} / \mu \mathrm{L}\right)$} & Negative & 615 & 2.43 & 363 & 2.73 \\
\hline & P. falciparum & 325 & $1.56 \dagger$ & 89 & $1.42 \dagger$ \\
\hline & $P$. vivax & 459 & $1.77 \dagger$ & 186 & $1.81 \dagger$ \\
\hline & Mixed $P f / P v$ & 19 & $1.52 \dagger$ & 4 & 2.18 \\
\hline & P. malariae & 14 & 2.04 & 1 & - \\
\hline
\end{tabular}

* Two subjects had missing sex information, one in the negative group and the other in the Plasmodium vivax group.

$\dagger P<0.001$, infected versus control group.

$\ddagger P<0.01$, infected versus control group.

$\S P<0.05$, infected versus control group.

persons with platelet counts $<150,000 / \mu \mathrm{L}$ were $12.5-14.7$ times more likely to have any of these malaria outcomes than persons with platelet counts $\geq 150,000 / \mu \mathrm{L}$. Fever and being ill for less than three days were also indicators in all the final models. Vomiting was a significant predictor in the $P$. falciparum models; malaise and lack of cough were predictors in the $P$. vivax models. A history of fever in the past 72 hours was a significant predictor of any malaria model only. For $P$. malariae infections, only low platelet and RBC counts were significant when controlling for the other factors, and only low platelet count and fever were significant for mixed infections.

\section{DISCUSSION}

The decreases observed in this study in WBC and lymphocyte counts associated with malaria infection are striking. While not all studies have found a decrease in leukocytes during malaria infection, ${ }^{4,5}$ this alteration is certainly not unprecedented, either for $P$. falciparum ${ }^{5,6}$ or for $P$. vivax ${ }^{5,7}$ The decreased levels of circulating lymphocytes were also expected from prior studies. ${ }^{6-8}$

Low platelet counts have been consistently found for both $P$. falciparum $^{4-6,8,9}$ and $P$. vivax ${ }^{4,7,10-13}$ A substantial proportion of cases in this study had very low platelet counts,

TABLE 3

Association between parasite densities (parasites $/ \mu \mathrm{L})$ and platelet $\operatorname{count}\left(\times 10^{3} / \mu \mathrm{L}\right)$

\begin{tabular}{|c|c|c|c|c|c|}
\hline & \multirow[b]{2}{*}{$\begin{array}{c}\text { Parasite } \\
\text { density range }\end{array}$} & \multicolumn{2}{|c|}{ Men } & \multicolumn{2}{|c|}{ Women } \\
\hline & & No.* & $\begin{array}{c}\text { Mean } \\
\text { platelet count }\end{array}$ & No.* & $\begin{array}{c}\text { Mean } \\
\text { platelet count }\end{array}$ \\
\hline Negative & 0 & 615 & 245.0 & 363 & 290.6 \\
\hline \multirow[t]{5}{*}{ P. falciparum } & $1-2,225$ & 84 & 158.5 & 15 & 169.4 \\
\hline & $2,226-10,300$ & 77 & 122.9 & 26 & 131.0 \\
\hline & $10,301-37,000$ & 82 & 117.5 & 25 & 137.3 \\
\hline & $>37,000$ & 82 & 105.2 & 23 & 109.0 \\
\hline & & \multicolumn{2}{|c|}{$\begin{array}{c}\text { Model } F \text { value }=8.23 \\
\qquad P<0.0001\end{array}$} & \multicolumn{2}{|c|}{$\begin{array}{c}\text { Model } \mathrm{F} \text { value }=3.06 \\
P=0.03\end{array}$} \\
\hline \multirow[t]{5}{*}{ P. vivax } & $1-525$ & 93 & 197.0 & 50 & 220.7 \\
\hline & $526-3,400$ & 131 & 139.4 & 43 & 158.3 \\
\hline & $3,401-9,500$ & 108 & 131.3 & 52 & 142.9 \\
\hline & $>9,500$ & 127 & 107.8 & 41 & 112.3 \\
\hline & & \multicolumn{2}{|c|}{$\begin{array}{c}\text { Model } \mathrm{F} \text { value }=37.94 \\
P<0.0001\end{array}$} & \multicolumn{2}{|c|}{$\begin{array}{c}\text { Model } \mathrm{F} \text { value }=19.2 \\
\qquad P<0.0001\end{array}$} \\
\hline
\end{tabular}

\footnotetext{
* Two subjects had missing sex information, one in the negative group and the other in the Plasmodium vivax group.
} 


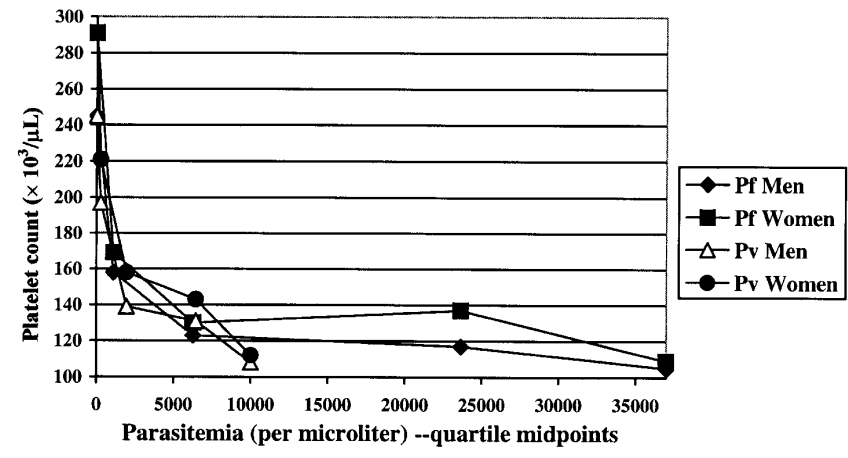

Figure 1. Platelet count by parasitemia in the study population. $\mathrm{Pf}=$ Plasmodium falciparum $; \mathrm{Pv}=P$. vivax . The $\mathrm{x}$-axis is truncated and the uppermost Pf quartile midpoint is 268,500 .

especially among those with $P$. falciparum infection, 39\% of whom had platelet counts less than $100,000 / \mu$ L. Plasmodium falciparum cases with platelet levels below this count have also been documented in other populations of semiimmune $^{4,5}$ and non-immune patients. ${ }^{6}$

The trend of decreasing platelet count with increasing levels of parasitemia observed in this study has been previously noted for $P$. falciparum, ${ }^{4,6}$ but to our knowledge, has not been documented in the literature for $P$. vivax. Decreased platelet production has been ruled out. ${ }^{5,11,14}$ Thrombocytopenia is a result of peripheral destruction and consumption. Immune complexes generated by malarial antigen lead to sequestration of the injured platelets by macrophages in the spleen. ${ }^{15-18}$ Platelet consumption in disseminated intravascular coagulation contributes to thrombocytopenia in complicated P. falciparum malaria; however, this process is not relevant to the present study population. Platelet dysfunction resulting in hyperaggregation is another alteration occurring in association with malaria resulting in hyperaggregation. ${ }^{19}$ During malaria infection, there are several factors that activate platelets, among which are formation of immune complexes and damage to endothelial cells. Surface contact of platelet membrane to with parasitized RBCs is another stimulator. ${ }^{20}$ Intravascular lysis of the activated platelets may also occur. ${ }^{9}$ Trends between increasing parasite density with a decrease in the level of hematologic parameters other than platelet count were not observed in this study, nor have they been consistently noted in the literature.

Anemia has frequently been associated with malaria. In regions of sub-Saharan Africa with stable, high malaria transmission, severe anemia is common among children or pregnant women infected with $P$. falciparum. ${ }^{21}$ Studies among non-immune or semi-immune populations outside Africa have also found statistically significant levels of mild anemia in falciparum malaria patients. ${ }^{4,5,22,23}$ Plasmodium vivax has been associated with mild anemia in some studies, ${ }^{7,10,12,24,25}$ but not in others. ${ }^{4}$ Two possible causes of this anemia are increased hemolysis or a decreased rate of erythrocyte production. ${ }^{26,27}$ Despite the extensive documentation of anemia in malaria, only mild decreases in $\mathrm{Hb}$ were observed in this study. This discrepancy may be related to the multifactorial etiology of anemia. The impact of malaria anemia is greatest in regions of sub-Saharan Africa where underlying anemia and poor nutrition are common. Although a few cases of very low $\mathrm{Hb}$ were observed among our study participants, only
$16 \%$ of all participants had even mild anemia ( $\mathrm{Hb}$ level $<11.0$ $\mathrm{g} / \mathrm{dL}$ ). Furthermore, some observers have suggested that malaria-related anemia is more severe in areas of intense malaria transmission and in younger children rather than in older children or adults. ${ }^{21,27}$ While this study and others in southeastern or eastern Asia have noted $\mathrm{Hb}$ decreases or mild anemia among malaria cases, ${ }^{4,7,10,23}$ the small degree of $\mathrm{Hb}$ change observed in this study population may reflect a lower prevalence of underlying anemia, better nutritional status, and/or better access to treatment.

Fever and history of fever are fairly sensitive measures of malaria, but they lack specificity or positive predictive value, especially in regions where malaria is less prevalent. The identification of signs or constellations of signs indicative of malaria could also help to improve appropriate treatment in areas where most people are parasitemic, but malaria diagnosis is still based solely on fever in the presence of any parasitemia. $^{28}$

Studies from various areas have failed to identify factors that can substantially improve upon current measures. The lack of specificity of malaria-associated signs and symptoms has led some researchers to conclude that only fever and history of fever have any real diagnostic value. ${ }^{29,30}$ A history of fever in the absence of another major symptom was the best predictor of malaria-positive blood slides in adults in Papua New Guinea, ${ }^{31}$ and a study in Zimbabwe concluded that only microscopy could improve diagnostic capabilities beyond those "unknown decision rules" used by health care workers. ${ }^{29}$ Combinations of factors have proved slightly better at identifying malaria. In Ethiopia, fever, previous malaria, and pallor was the measure with the best combined sensitivity and specificity. ${ }^{32}$ The identification of additional criteria helpful in diagnosing malaria would be of use in this field.

The symptoms found in this study to be independently associated with the presence of malaria parasites have been well recognized: oral temperature $\geq 38.5^{\circ} \mathrm{C}$, history of fever in the past 72 hours, malaise, chills, and (for $P$. falciparum) vomiting. Associations between low WBC, RBC, or platelet counts and malaria infection are not as widely acknowledged, in part because they are not routinely obtained at malaria clinics. These parameters, however, appear to have the strongest independent measures of association besides fever; crude odds ratios as high as 23 are observed for low platelet count and the presence of $P$. falciparum. Even when controlling for other clinical factors, platelet count still has a higher predictive value for malaria infection than any symptoms. A person from this study population infected with $P$. falciparum is almost 15 times more likely to have a low platelet count $(<150,000 / \mu \mathrm{L})$ than a malaria-negative one, adjusting for fever, vomiting, days ill, RBCs, and WBCs.

Platelet count may be of limited diagnostic applicability in settings where health care workers must operate without even the benefits of a microscope. However, in Thailand, capability of a routine $\mathrm{CBC}$ is available at all district-level hospitals. Interestingly, malaria diagnosis at those hospitals is sometimes less accurate than at malaria clinics because of reliance on only thin blood films or the limited experience of hospital microscopists in detecting malaria parasites or in reading a thick smear compared with specially-trained malaria clinic microscopists. Also, patients presenting to district hospitals often have prior self-treatment with ineffective or sub- 
TABLE 4

Independent associations between symptoms or hematologic parameters and malaria infection*

\begin{tabular}{|c|c|c|c|c|c|c|c|c|c|c|c|}
\hline & & \multirow{2}{*}{$\begin{array}{c}\text { Negative } \\
(\mathrm{n}=979) \\
\text { No. }\end{array}$} & \multicolumn{3}{|c|}{$\begin{array}{l}\text { P. falciparum } \\
(\mathrm{n}=414)\end{array}$} & \multicolumn{3}{|c|}{$\begin{array}{c}\text { P. vivax } \\
(\mathrm{n}=646)\end{array}$} & \multicolumn{3}{|c|}{$\begin{array}{l}P_{(\mathrm{n}} \text { malariae } \\
(\mathrm{n}=15)\end{array}$} \\
\hline & & & No. & OR & $95 \% \mathrm{CI}$ & No. & OR & $95 \% \mathrm{CI}$ & No. & OR & $95 \% \mathrm{CI}$ \\
\hline \multirow[t]{2}{*}{ Age (years) } & $<40$ & 833 & 364 & Ref & & 566 & Ref & & 14 & Ref & \\
\hline & $\geq 40$ & 146 & 50 & 0.8 & $(0.6,1.1)$ & 80 & 0.8 & $(0.6,1.1)$ & 1 & 0.4 & $(0.1,3.1)$ \\
\hline \multirow{3}{*}{ White blood cells $/ \mu \mathrm{l}$} & $<5,000$ & 67 & 112 & 4.2 & $(3.0,5.8) \dagger$ & 135 & 3.0 & $(2.2,4.1) \dagger$ & 5 & 5.3 & $(1.8,15.9) \ddagger$ \\
\hline & $5,000-10,000$ & 709 & 284 & Ref & & 474 & Ref & & 10 & Ref & \\
\hline & $>10,000$ & 203 & 18 & 0.2 & $(0.1,0.4) \dagger$ & 37 & 0.3 & $(0.2,0.4) \dagger$ & 0 & - & - \\
\hline \multirow[t]{2}{*}{ Red blood cells $/ \mu \mathrm{L}$} & $<4,000,000$ & 75 & 80 & 2.9 & $(2.1,4.1) \dagger$ & 81 & 1.7 & $(1.2,2.4) \ddagger$ & 7 & 10.5 & $(3.7,29.9) \dagger$ \\
\hline & $\geq 4,000,000$ & 904 & 334 & Ref & & 565 & Ref & & 8 & Ref & \\
\hline \multirow[t]{2}{*}{ Platelets/ $\mu \mathrm{l}$} & $<150,000$ & 79 & 279 & 23.5 & $(17.3,32.1) \dagger$ & 377 & 16.0 & $(12.1,21.1) \dagger$ & 11 & 31.3 & $(9.7,101) \dagger$ \\
\hline & $\geq 150,000$ & 900 & 135 & Ref & & 269 & Ref & & 4 & Ref & \\
\hline \multirow{2}{*}{ Headache } & No & 14 & 5 & Ref & & 11 & Ref & & 2 & Ref & \\
\hline & Yes & 965 & 409 & 1.2 & $(0.4,3.3)$ & 635 & 0.8 & $(0.4,1.9)$ & 13 & 0.1 & $(0.02,0.5) \dagger$ \\
\hline \multirow[t]{2}{*}{ Fever $\left({ }^{\circ} \mathrm{C}\right)$} & $<38.5$ & 850 & 195 & Ref & & 412 & Ref & & 13 & Ref & \\
\hline & $\geq 38.5$ & 129 & 219 & 7.4 & $(5.7,9.7) \dagger$ & 234 & 3.7 & $(2.9,4.8) \dagger$ & 2 & 1.0 & $(0.2,4.5)$ \\
\hline \multirow[t]{2}{*}{ History of fever, past 72 hours } & No & 67 & 7 & Ref & & 17 & Ref & & 1 & Ref & \\
\hline & Yes & 912 & 407 & 4.3 & $(1.9,9.4) \dagger$ & 629 & 2.7 & $(1.6,4.7) \dagger$ & 14 & 1.0 & $(0.1,7.9)$ \\
\hline \multirow[t]{2}{*}{ Vomiting } & No & 792 & 259 & Ref & & 510 & Ref & & 14 & Ref & \\
\hline & Yes & 187 & 155 & 2.5 & $(2.0,3.3) \dagger$ & 136 & 1.1 & $(0.9,1.4)$ & 1 & 0.3 & $(0.03,2.3)$ \\
\hline \multirow[t]{2}{*}{ Malaise } & No & 433 & 105 & Ref & & 165 & Ref & & 5 & Ref & \\
\hline & Yes & 546 & 309 & 2.3 & $(1.8,3.0) \dagger$ & 481 & 2.3 & $(1.9,2.9) \dagger$ & 10 & 1.6 & $(0.5,4.7)$ \\
\hline \multirow[t]{2}{*}{ Myalgias } & No & 58 & 15 & Ref & & 20 & Ref & & 2 & Ref & \\
\hline & Yes & 921 & 399 & 1.7 & $(0.9,3.0)$ & 626 & 2.0 & $(1.2,3.3) \ddagger$ & 13 & 0.4 & $(0.1,1.9)$ \\
\hline \multirow[t]{2}{*}{ Cough } & No & 788 & 340 & 1.1 & $(0.5,1.5)$ & 559 & 1.6 & $(1.2,2.1) \ddagger$ & 12 & 1.0 & $(0.3,3.5)$ \\
\hline & Yes & 191 & 74 & Ref & & 87 & Ref & & 3 & Ref & \\
\hline \multirow[t]{2}{*}{ Diarrhea } & No & 957 & 403 & Ref & & 634 & Ref & & 15 & Ref & \\
\hline & Yes & 22 & 11 & 1.2 & $(0.6,2.5)$ & 12 & 0.8 & $(0.4,1.7)$ & 0 & - & - \\
\hline \multirow[t]{2}{*}{ Chills } & No & 227 & 48 & Ref & & 75 & Ref & & 2 & Ref & \\
\hline & Yes & 752 & 366 & 2.3 & $(1.6,3.2) \dagger$ & 571 & 2.3 & $(1.7,3.0) \dagger$ & 13 & 2.0 & $(0.4,8.8)$ \\
\hline \multirow[t]{2}{*}{ Days ill } & $\leq 3$ & 719 & 311 & 1.1 & $(0.8,1.4)$ & 500 & 1.2 & $(1.0,1.6)$ & 9 & 1.8 & $(0.6,5.2)$ \\
\hline & $>3$ & 260 & 103 & Ref & & 146 & Ref & & 6 & Ref & \\
\hline
\end{tabular}

* OR $=$ odds ratio $; \mathrm{CI}=$ confidence interval; $\mathrm{Ref}=$ referent

$\dagger P<0.001$.
$\dagger P<0.01$.

therapeutic doses of antimalarials. Such treatment may suppress the parasites or distort their morphology, but not fully eliminate them. Therefore, in this malaria-endemic area, an acutely febrile patient with low platelet count and a reduced WBC count, irrespective of a malaria smear report, should always be thoroughly re-evaluated for malaria. A recent study also identified a prognostic value for thrombocytopenia in African children, with a lower platelet count associated with more severe illness or outcome. ${ }^{33}$ While prognosis could not be evaluated in this study, platelets might play a similar role in this population.
This study used very rigorous microscopy procedures, which should minimize misclassification of malaria status. Additionally, the large sample size and high proportion of malaria cases give this analysis substantial power to detect differences between cases and controls. Daily quality control checks of the automated cell counters maintained the accuracy and precision of the hematologic measurements.

One limitation of this study is that the controls are symptomatic, febrile individuals, and therefore do not represent a healthy population. They are likely to have had a diverse collection of bacterial and viral ailments that could affect the

TABLE 5

Adjusted odds ratios (ORs) and 95\% confidence intervals (CIs) for parameters associated with malaria infection

\begin{tabular}{|c|c|c|c|c|c|c|}
\hline & \multicolumn{2}{|c|}{ Any malaria } & \multicolumn{2}{|c|}{ P. falciparum } & \multicolumn{2}{|c|}{ P. vivax } \\
\hline & OR & $95 \% \mathrm{CI}$ & OR & $95 \% \mathrm{CI}$ & OR & $95 \% \mathrm{CI}$ \\
\hline White blood cells $<5000 / \mu \mathrm{L}$ & 1.6 & $(1.1,2.2)$ & 1.2 & $(0.8,1.9)$ & 1.6 & $(1.1,2.4)$ \\
\hline White blood cells $>10,000 / \mu \mathrm{L}$ & 0.3 & $(0.2,0.5)$ & 0.2 & $(0.1,0.4)$ & 0.4 & $(0.2,0.5)$ \\
\hline Red blood cells $<4,000,000 / \mu \mathrm{L}$ & 1.7 & $(1.2,2.5)$ & 1.9 & $(1.2,3.1)$ & & - \\
\hline Platelets $<150,000 / \mu \mathrm{L}$ & 12.8 & $(9.7,16.9)$ & 14.7 & $(10.4,21.3)$ & 12.5 & $(9.3,16.9)$ \\
\hline Fever $\geq 38.5^{\circ} \mathrm{C}$ & 2.4 & $(1.8,3.1)$ & 3.3 & $(2.3,4.6)$ & 1.8 & $(1.3,2.5)$ \\
\hline Days ill $\leq 3$ & 1.9 & $(1.5,2.5)$ & 2.2 & $(1.5,3.2)$ & 2.0 & $(1.5,2.8)$ \\
\hline History of fever, 72 hours & 1.9 & $(1.0,3.3)$ & & - & & - \\
\hline Malaise & 1.5 & $(1.2,1.9)$ & & - & 1.9 & $(1.4,2.5)$ \\
\hline No cough & 1.4 & $(1.0,1.8)$ & & - & 1.5 & $(1.1,2.1)$ \\
\hline Vomiting & & - & 1.9 & $(1.3,2.7)$ & & - \\
\hline Logistic regression & \multicolumn{2}{|c|}{$\begin{array}{c}\text { Model } \mathrm{R}^{2}=0.35 \\
\text { Wald } \chi^{2}=523 \\
P<0.0001\end{array}$} & \multicolumn{2}{|c|}{$\begin{array}{c}\text { Model } \mathrm{R}^{2}=0.36 \\
\text { Wald } \chi^{2}=383 \\
P<0.0001\end{array}$} & \multicolumn{2}{|c|}{$\begin{array}{c}\text { Model } \mathrm{R}^{2}=0.31 \\
\text { Wald } \chi^{2}=396 \\
P<0.0001\end{array}$} \\
\hline
\end{tabular}


measured hematologic variables in different ways. Nonetheless, the mean hematologic parameters for the control group fell within the standard normal ranges measured in other populations. Another caution in interpreting our data is that the statistically significant differences found between malaria cases and controls in many of the measured parameters do not necessarily indicate clinical significance.

Although these basic hematologic changes in association with malaria are not new to the subject, our data add more detailed information to the limited body of knowledge. The observations of thrombocytopenia and lymphopenia are in accordance with those reported in non-immune individuals, ${ }^{6}$ and are unlike observations reported from sub-Saharan Africa. This study implies that malaria must always be a key differential diagnosis in acutely febrile patients with thrombocytopenia and leukopenia from this endemic area. This is the first documentation that the parallel trend in thrombocytopenia with parasitemia is not only unique for infection with $P$. falciparum, but also with $P$. vivax. Greater exploration of the strong, inverse relationship between platelet levels and malaria infection may afford means to improve diagnosis and alleviate the clinical severity of or accelerate recovery from this disease.

Received July 11, 2003. Accepted for publication September 20, 2003.

Acknowledgments: This work was presented at the 51st Annual Meeting of the American Society of Tropical Medicine and Hygiene (Denver, CO) on November 12, 2002 by Laura M. Erhart (Abstract No. 242, Scientific Session J, Malaria Epidemiology and Diagnosis). We thank Dr. J. Sirichaisinthop for his support, and to the Malaria Field Team of the Department of Immunology of the Armed Forces Research Institute of Medical Sciences for technical assistance.

Financial support: This study was supported by U.S. Army Medical Materiel Development Activity (Fort Detrick, Frederick, MD).

Disclaimer: The opinions or assertions contained herein are those of the authors and should not be construed as reflecting the official positions of the U.S. Army, U.S. Air Force, or U.S. Department of Defense.

Authors' addresses: Laura M. Erhart, Department of Immunology and Medicine, Armed Forces Research Institute of Medical Sciences, 315/6 Rajvithi Road, Bangkok 10400, Thailand, and University of Michigan School of Public Health, Ann Arbor, MI 48109-2029. Kritsanai Yingyuen, Niphon Chuanak, Nilawan Buathong, Anintita Laoboonchai, and R. Scott Miller, Department of Immunology and Medicine, Armed Forces Research Institute of Medical Sciences, 315/6 Rajvithi Road, Bangkok 10400, Thailand. Chansuda Wongsrichanalai, U.S. Naval Medical Research Unit No. 2, Kompleks P2M/PLP-LITBANGKES, Jalan Percetakan Negara No. 29, Jakarta 10570, Indonesia, Telephone: 62-21-421-4457 extension 1121, Fax: 6221-420-7854. E-mail: chansuda@namru2.med.navy.mil. Steven R. Meshnick, University of North Carolina School of Public Health, Chapel Hill, NC 27599-7435. Robert A. Gasser Jr., Walter Reed Army Institute of Research, 503 Robert Grant Avenue, Silver Spring, MD 20910.

\section{REFERENCES}

1. Price RN, Simpson JA, Nosten F, Luxemburger C, Hkirjaroen L, ter Kuile F, Chongsuphajaisiddhi T, White NJ, 2001. Factors contributing to anemia after uncomplicated falciparum malaria. Am J Trop Med Hyg 65: 614-622.

2. Forney JR, Wongsrichanalai C, MagillAJ, Craig LG, Sirichaisinthop J, Bautista CT, Miller RS, Ockenhouse CF, Kester KE, Aronson NE, Andersen EM, Quino-Ascurra HA, Vidal C, Moran KA, Murray CK, DeWitt CC, Heppner DG, Kain KC, Ballou WR, Gasser RA Jr, 2003. Devices for rapid diagnosis of malaria: evaluation of prototype assays that detect Plasmodium falciparum histidine-rich protein 2 and a Plasmodium vivax-specific antigen. J Clin Microbiol 41: 2358-2366.

3. Mazza JJ, 1995. Manual of Clinical Hematology. Boston: Little, Brown and Company.

4. Rojanasthien S, Surakamolleart V, Boonpucknavig S, Isarangkura $\mathrm{P}, 1992$. Hematological and coagulation studies in malaria. J Med Assoc Thai 75: 190-194.

5. Perrin LH, Mackey LJ, Miescher PA, 1982. The hematology of malaria in man. Semin Hematol 19: 70-82.

6. Richards MW, Behrens RH, Doherty JF, 1998. Short report: Hematologic changes in acute, imported Plasmodium falciparum malaria. Am J Trop Med Hyg 59: 859.

7. Lee HK, Lim J, Kim M, Lee S, Oh EJ, Lee J, Oh J, Kim Y, Han K, Lee EJ, Kang CS, Kim BK, 2001. Immunological alterations associated with Plasmodium vivax malaria in South Korea. Ann Trop Med Parasitol 95: 31-39.

8. Wickramasinghe SN, Abdalla SH, 2000. Blood and bone marrow changes in malaria. Baillieres Best Pract Res Clin Haematol 13: 277-299.

9. Essien EM, 1989. The circulating platelet in acute malaria infection. Br J Haematol 72: 589-590.

10. Kueh YK, Yeo KL, 1982. Haematological alterations in acute malaria. Scand J Haematol 29: 147-152.

11. Neva FA, Sheagren JN, Shulman NR, Canfield CJ, 1970. Malaria: host-defense mechanisms and complications. Ann Intern Med 73: 295-306.

12. Oh MD, Shin H, Shin D, Kim U, Lee S, Kim N, Choi MH, Chai JY, Choe K, 2001. Clinical features of vivax malaria. Am J Trop Med Hyg 65: 143-146.

13. Yamaguchi S, Kubota T, Yamagishi T, Okamoto K, Izumi T, Takada M, Kanou S, Suzuki M, Tsuchiya J, Naruse T, 1997. Severe thrombocytopenia suggesting immunological mechanisms in two cases of vivax malaria. Am J Hematol 56: 183-186.

14. Srichaikul T, Panikbutr N, Jeumtrakul P, 1967. Bone-marrow changes in human malaria. Ann Trop Med Parasitol 61: 40-51.

15. Skudowitz RB, Katz J, Lurie A, Levin J, Metz J, 1973. Mechanisms of thrombocytopenia in malignant tertian malaria. BBMJ 2: 515-518.

16. Beale PJ, Cormack JD, Oldrey TB, 1972. Thrombocytopenia in malaria with immunoglobulin (IgM) changes. BMJ 5: 345-349.

17. Kelton JG, Keystone J, Moore J, Denomme G, Tozman E, Glynn M, Neame PB, Gauldie J, Jensen J, 1983. Immune-mediated thrombocytopenia of malaria. J Clin Invest 71: 832-836.

18. Looareesuwan S, Davis JG, Allen DL, Lee SH, Bunnag D, White NJ, 1992. Thrombocytopenia in malaria. Southeast Asian J Trop Med Public Health 23: 44-50.

19. Mohanty D, Marwaha N, Ghosh K, Sharma S, Garewal G, Shah S, Devi S, Das KC, 1988. Functional and ultrastructural changes of platelets in malarial infection. Trans $R$ Soc Trop Med Hyg 82: 369-375.

20. Inyang AL, Sodeinde O, Okpako DT, Essien EM, 1987. Platelet reactions after interaction with cultured Plasmodium falciparum infected erythrocytes. Br J Haematol 66: 375-378.

21. Menendez C, Fleming AF, Alonso PL, 2000. Malaria-related anaemia. Parasitol Today 16: 469-476.

22. Das BS, Nanda NK, Rath PK, Satapathy RN, Das DB, 1999. Anaemia in acute, Plasmodium falciparum malaria in children from Orissa state, India. Ann Trop Med Parasitol 93: 109-119.

23. Phillips RE, Looareesuwan S, Warrell DA, Lee SH, Karbwang J, Warrell MJ, White NJ, Swasdichai C, Weatherall DJ, 1986. The importance of anaemia in cerebral and uncomplicated falciparum malaria: role of complications, dyserythropoiesis and iron sequestration. $Q J$ Med 58: 305-323.

24. Kumaresan PR, Selvam R, 1991. The haematology of Plasmodium vivax before and after chloroquine and primaquine treatment in north Madras area. Indian J Malariol 28: 115-120.

25. Selvam R, Baskaran G, 1996. Hematological impairments in recurrent Plasmodium vivax infected patients. Jpn J Med Sci Biol 49: 151-165.

26. Weatherall DJ, 1988. The anaemia of malaria. McGregor I, Wernsdorfer WH, eds. Malaria: Principles and Practice of Malariology. New York: Churchill Livingstone, 735-751.

27. Phillips RE, Pasvol G, 1992. Anaemia of Plasmodium falciparum malaria. Baillieres Clin Haematol 5: 315-330. 
28. Armstrong Schellenberg JRM, Smith T, Alonso PL, Hayes RJ, 1994. What is clinical malaria? Finding case definitions for field research in highly endemic areas. Parasitol Today 10: 439-444.

29. Bassett M, Taylor P, Bvirakare J, Chiteka F, Govere E, 1991. Clinical diagnosis of malaria: can we improve? J Trop Med Hyg 94: 65-69.

30. Rooth I, Bjorkman A, 1992. Fever episodes in a holoendemic malaria area of Tanzania: parasitological and clinical findings and diagnostic aspects related to malaria. Trans $R$ Soc Trop Med Hyg 86: 479-482.
31. Genton B, Smith T, Baea K, Narara A, Al Yaman F, Beck HP, Hii J, Alpers M, 1994. Malaria: how useful are clinical criteria for improving the diagnosis in a highly endemic area? Trans $R$ Soc Trop Med Hyg 88: 537-541.

32. Muhe L, Oljira B, Degefu H, Enquesellassie F, Weber MW, 1999. Clinical algorithm for malaria during low and high transmission seasons. Arch Dis Child 81: 216-220.

33. Gerardin P, Rogier C, Ka A, Jouvencel P, Brousse V, Imbert P, 2002. Prognostic value of thrombocytopenia in African children with falciparum malaria. Am J Trop Med Hyg 66: 686-691. 